\title{
PENINGKATAN EFEKTIVITAS PEMBELAJARAN DENGAN PENGUATAN IKLIM SEKOLAH, DAN PENGETAHUAN GURU TENTANG KURIKULUM 2013
}

\author{
Indri Wulandari $^{a)}$, Eka Suhardi ${ }^{\left.b^{*}\right)}$ \\ a) SMA Negeri Kota Sukabumi, Sukabumi, Indonesia \\ b) Universitas Pakuan, Bogor, Indonesia \\ *)e-mail korespondensi: eka.suhardi@unpak.ac.id
}

riwayat artikel : diterima: 06 November 2019; direvisi: 16 November 2019; disetujui: 06 Desember 2019

\begin{abstract}
Abstrak. Penelitian Penelitian ini bertujuan untuk mengetahui bagaimana efektivitas pembelajaran dapat ditingkatkan dengan cara mengkaji hubungan antara: 1) iklim sekolah dengan efektivitas pembelajaran, 2) pengetahuan guru tentang kurikulum 2013 dengan efektivitas pembelajaran, 3) iklim sekolah dan pengetahuan guru tentang kurikulum 2013 secara bersama-sama dengan efektivitas pembelajaran. Penelitian ini menggunakan metode survei dengan pendekatan korelasional yang dilaksanakan pada guru pegawai negeri di SMAN Kota Sukabumi. Populasi pada penelitian ini berjumlah 254 orang dengan sampel sebanyak 155 orang. Pengumpulan data untuk setiap variabel yang diteliti menggunakan angket dan tes. Teknik analisis menggunakan korelasi regresi dan korelasi parsial. Hasil penelitain menghasilkan tiga kesimpulan yaitu: pertama, terdapat hubungan positif antara iklim sekolah dengan efektivitas pembelajaran. Kedua, terdapat hubungan positif antara pengetahuan guru tentang kurikulum 2013 dengan efektivitas pembelajaran. Ketiga, terdapat hubungan positif antara iklim sekolah dan pengetahuan guru tentang kurikulum 2013 secara bersamasama dengan efektivitas pembelajaran.
\end{abstract}

Kata Kunci: efektivitas pembelajaran, iklim sekolah, pengetahuan guru tentang kurikulum 2013.

\section{IMPROVING LEARNING EFFECTIVENESS WITH STRENGTHENING SCHOOL ACADEMIC ATMOSPHERE, AND TEACHER KNOWLEDGE ABOUT 2013 CURRICULUM}

\begin{abstract}
This study aimed to determine how the learning effectiveness can be improved by examining the relationship between, 1) a school climate by learning effectiveness, 2) knowledge of the teachers about the curriculum 2013 with the effectiveness of learning, 3) the climate of the school and the teacher's knowledge of curriculum 2013 together with the effectiveness of learning. This study used a survey method with the correlational approach undertaken in servant teachers at SMAN Sukabumi. The population in this study amounted to 254 with a sample of 155 people. The collection of data for each variable studied was using questionnaires and tests. The statistical analysis was using regression correlation and partial correlation. The result produced three conclusions: firstly, there was a positive relationship between school climate by learning effectiveness. Secondly, there was a positive relationship between teachers' knowledge of curriculum 2013 with the effectiveness of learning. Thirdly, there was a positive relationship between school climate and teacher's knowledge of the curriculum 2013 together with the effectiveness of learning.
\end{abstract}

Keywords: learning effectiveness, school climate, teacher's knowledge of the curriculum 2013

\section{PENDAHULUAN}

Upaya mencapai tujuan pendidikan menuntut peningkatan kualitas pendidikan itu sendiri (Hidayat, 2018). Salah satu indikator kualitas pendidikan yang unggul adalah efektivitas dalam pembelajaran yang memungkinkan siswa belajar dengan mudah dan menyenangkan, yang menunjang tercapainya penguasaan kompetensi dan tujuan pembelajaran. Sampai pada titik ini, nyata bahwa peran efektivitas guru dalam mengajar sangatlah penting.

Guru yang efektif trampil mengelola kelas, memfasilitasi proses pembelajaran interaktif yang menarik minat siswa, menyampaikan materi ajar dengan efektif dan menarik sehingga mudah dipahami siswa. Pembelajaran yang efektif akan mendorong siswa menjadi aktif, kritis dan menunjukkan minat untuk lebih memahami pelajaran. Pembelajaran yang efektif dapat menggerakkan fisik dan mental serta sosial siswa.

Lingkungan sekolah yang nyaman, kondisi kerja guru dan warga sekolah lainnya yang kondusif adalah salah satu prasyarat terwujudnya pembelajaran yang efektif. Didukung oleh metode pembelajaran yang menyenangkan di kelas melalui pendekatan ilmiah serta penggabungan teknologi terbaru. Kompetensi pedagogi guru menuntut mereka memiliki pengetahuan yang memadai tentang kurikulum pada 2013, yang akan berdampak pula pada proses pembelajaran. Kemahiran dalam implementasi Kurikulum 2013, diharapkan guru dapat melakukan manajemen kelas yang efektif sesuai dengan rencana pelajaran yang telah dikembangkan sebelumnya, agar siswa terdorong lebih aktif. 
Berdasarkan pemikiran di atas perlu dilakukan penelitian untuk mengungkapkan bagaimana cara meningkatkan efektivitas pembelajaran sebagai variabel utama juga menghubungkan dengan variabel lain yang diduga terdapat hubungan dengan efektivitas pembelajaran yaitu iklim sekolah dan pengetahuan guru tentang kurikulum 2013.

\section{Efektivitas Pembelajaran}

Efektivitas proses pembelajaran adalah tingkat keberhasilan guru dalam mengajar kelompok siswa tertentu, dengan cara tertentu untuk mencapai tujuan pengajaran tertentu (Yulita, 2014:109). Bungai (2006:92) merumuskan pembelajaran yang efektif sebagai pengajaran yang menciptakan lingkungan yang kondusif bagi siswa untuk belajar dengan baik. Budaya sekolah dapat diidentifikasikan dari setiap lapisan budaya sekolah yang terbagi dua yaitu lapisan yang dapat diamati dan lapisan yang tersembunyi atau lapisan yang tidak dapat diamati (Pertiwi, 2019). Indikasinya adalah: a. memungkinkan pembelajaran aktif dengan memungkinkan siswa untuk belajar kapan saja, di mana saja, b. memfasilitasi kerja sama dan kerja tim dengan menyediakan fungsionalitas seperti kolaborasi virtual, c. meningkatkan pembelajaran dengan memfasilitasi kerja tim dan proyek kelompok, d. memberikan pengetahuan atau informasi tentang dunia nyata ( Sheng, Siau \& Well, 2010:36).

Supardi (2013:163) menjelaskan bahwa pembelajaran yang efektif adalah kombinasi terstruktur yang mencakup manusia, bahan, fasilitas, peralatan dan prosedur yang diarahkan untuk mengubah perilaku siswa ke arah yang positif baik sesuai dengan potensi dan keragaman siswa untuk mencapai tujuan pembelajaran yang telah ditetapkan.

Berdasarkan teori-teori di atas dapat disusun sintesis efektivitas belajar, yaitu ukuran keberhasilan proses interaksi dalam situasi pendidikan untuk mencapai tujuan pembelajaran, pandangan siswa selama kegiatan pembelajaran, respon dan penguasaan konsep. Indikator yang digunakan: a. keterlibatan siswa di dalam kelas, b. pendayagunaan sarana dan prasarana, c. hasil belajar dan d. koordinasi guru.

\section{Iklim Sekolah}

Iklim sekolah adalah tingkat kenyamanan dan keamanan sekolah sebagai tempat kerja (Pratiwi, 2013:92). Menurut Herman dan Cohen (2018:271) iklim sekolah mempengaruhi kinerja akademik, lingkungan sekolah yang lebih luas, perilaku siswa, dan pengalaman. iklim sekolah adalah kualitas dan karakter kehidupan sekolah dan mencerminkan norma, tujuan, nilai, hubungan interpersonal, praktik belajar mengajar dan struktur organisasi sekolah (Bao et al, 2015:81). Menurut Rapti (2012:111) iklim sekolah didefinisikan sebagai campuran kepercayaan, nilai-nilai dan perilaku siswa, fakultas, pemimpin dan orang tua, tingkat kemandirian, fleksibilitas gaya dan kepuasan kerja. Goldstein dan Brooks (2013:413) iklim sekolah mengacu pada kualitas dan karakter kehidupan sekolah.

Menurut Freiberg (2005), ikllim sekolah adalah suasana atau kualitas dari sekolah untuk membantu masing-masing warga sekolah untuk merasa berharga secara pribadi, bermartabat dan penting secara serentak dapat membantu terciptanya suatu perasaan memiliki terhadap segala sesuatu di sekitar lingkungan sekolah.

\section{Pengetahuan Guru Tentang Kurikulum 2013}

Park dan Oliver (2008:266) memaparkan bahwa pemahaman guru tentang pentingnya topik, relatif signifikan terhadap kompetensi dalam melaksanakan kurikulum secara keseluruhan. Disisi lain, guru tidak dapat mengembangkan pengetahuan mengenai evaluasi secara terpisah dari pengetahuan mereka tentang konten pedagogis, hal ini penting karena mereka perlu mengarahkan fokus proses pengajaran mereka pada pemenuhan kebutuhan siswa (Timperley, 2008:11).

Afadil dan Poedjiastoeti (2016:66) menyatakan bahwa untuk melaksanakan tuntutan pembelajaran sesuai dengan kurikulum pada tahun 2013 diperlukan beberapa kemampuan guru, yaitu: a. memahami materi dasar oleh guru, b. mengeksploitasi materi pelajaran untuk meningkatkan karakter, c. memanfaatkan teknologi secara optimal dalam pembelajaran.

Permendikbud No. 65 Tahun 2013 tentang Standar Proses Pendidikan Dasar dan Menengah telah mengisyaratkan tentang perlunya proses pembelajaran yang dipandu dengan kaidah-kaidah pendekatan saintifik/ilmiah (Kemendikbud, 2013). Proses pembelajaran dapat dipadankan dengan suatu proses ilmiah, yang lebih mengedepankan penalaran induktif (inductive reasoning) ketimbang penalaran deduktif (deductive reasoning). Proses pembelajaran dengan berbasis pendekatan saintifik harus dipadu dengan kaidah-kaidah pendekatan ilmiah yang bercirikan penonjolan dimensi pengamatan, penalaran, penemuan, pengabsahan, dan penjelasan tentang suatu kebenaran. Proses pembelajaran pada Kurikulum 2013 untuk semua jenjang dilaksanakan dengan menggunakan pendekatan saintifik dan menyentuh tiga ranah, yaitu sikap, pengetahuan, dan ketrampilan. Hasil akhirnya adalah peningkatan dan keseimbangan antara kemampuan untuk menjadi manusia baik (soft skills) dan manusia yang memiliki kecakapan dan pengetahuan untuk hidup secara layak (hard skills) dari peserta didik yang meliputi aspek kompetensi sikap, ketrampilan, dan pengetahuan (Kemendikbud, 2013, p. 187). Kemendikbud (2013, pp. 187-188) memberikan konsepsi tersendiri bahwa pada Kurikulum 2013 menekankan pada dimensi pedagogik modern dalam pembelajaran, yaitu menggunakan pendekatan ilmiah. Pendekatan ilmiah (scientific approach) dalam pembelajaran sebagaimana dimaksud meliputi mengamati, menanya, mengolah, menyajikan data dan mengomunikasikannya untuk semua mata pelajaran.

Berdasarkan berbagai pendapat yang dikemukakan di atas, dapat disintesis bahwa pengetahuan guru tentang kurikulum 2013 adalah kemampuan guru mengetahui standar isi, standar proses dan standar evaluasi terkait pendekatan saintifik dalam proses pembelajaran dan penilaian otentik pada hasil belajarnya dengan indikator: a. pemahaman kebijakan kurikulum 2013, b. pembelajaran saintifik, c. penilaian otentik, d. pengembangan peserta didik. 


\section{METODE PENELITIAN}

Penelitian ini menggunakan metode survei dengan pendekatan korelasional, dengan variabel bebas yang diteliti adalah iklim sekolah $\left(\mathrm{X}_{1}\right)$ dan pengetahuan guru tentang kurikulum $2013\left(\mathrm{X}_{2}\right)$, variabel terikatnya adalah efektivitas pembelajaran $(\mathrm{Y})$. Penelitian ini bertujuan untuk mengetahui bagaimana efektivitas pembelajaran dapat ditingkatkan dengan cara mengkaji hubungan antara: 1) iklim sekolah dengan efektivitas pembelajaran, 2) pengetahuan guru tentang kurikulum 2013 dengan efektivitas pembelajaran, 3) iklim sekolah dan pengetahuan guru tentang kurikulum 2013 secara bersama-sama dengan efektivitas pembelajaran. Penelitian dilaksanakan pada guru pegawai negeri di SMAN Kota Sukabumi. Populasi pada penelitian ini berjumlah 254 orang dengan sampel sebanyak 155 orang. Pengumpulan data untuk setiap variabel yang diteliti menggunakan angket dan tes. Teknik analisis menggunakan korelasi regresi dan korelasi parsial.

\section{HASIL DAN PEMBAHASAN}

\section{Pengujian persyaratan analisis \\ Uji Normalitas}

Uji normalitas data diuji pada nilai residual regresi menggunakan Uji Kolmogorov-Smirnov. Hasil pengujian menunjukan nilai Asymp. Sig (2-tailed) sebesar 0,257>0,05 yang menunjukan normalitas (Y-Ŷ1) variabel efektivitas pembelajaran atas iklim sekolah berasal dari populasi pada model regresi telah berdistribusi normal.

Uji normalitas data diuji pada nilai residual regresi menggunakan Uji Kolmogorov-Smirnov. Hasil pengujian menunjukan nilai Asymp. Sig (2-tailed) sebesar 0,227 > 0,05 yang menunjukan normalitas (Y-Ŷ1) variabel efektivitas pembelajaran atas pengetahuan guru tentang kurikulum 2013 berasal dari populasi pada model regresi telah berdistribusi normal.

\section{Uji Homogenitas}

Homogenitas varians kelompok data varabel efektivitas pembelajaran (Y) atas iklim sekolah $\left(\mathrm{X}_{1}\right)$ hasil pengujiannya diperoleh nilai Levene statistic sebesar 1,268 dengan signifikansi 0,206. Karena nilai Sig. > 0,05. Kesimpulannya variansi skor data variabel efektivitas pembelajaran $(\mathrm{Y})$ atas iklim sekolah $\left(\mathrm{X}_{1}\right)$ dikelompokan adalah berasal dari populasi yang homogen.

Homogenitas varians kelompok data varabel efektivitas pembelajaran $(Y)$ atas pengetahuan guru tentang kurikulum 2013 $\left(\mathrm{X}_{2}\right)$ hasil pengujiannya diperoleh nilai Levene statistic sebesar 1,208 dengan signifikansi 0,291. Karena nilai Sig. > 0,05. Kesimpulannya variansi skor data variabel efektivitas pembelajaran (Y) atas pengetahuan guru tentang kurikulum $2013\left(\mathrm{X}_{2}\right)$ dikelompokan adalah berasal dari populasi yang homogen.

\section{Pengujian Hipotesis}

\section{Hubungan antara iklim sekolah dengan efektivitas pembelajaran}

Hasil analisis regresi sederhana antara iklim sekolah dengan efektivitas pembelajaran diperoleh persamaan regresi $\hat{Y}=$ $64,208+0,504 \mathrm{X}_{1}$ yang signifikan dibuktikan dengan diperoleh $\mathrm{F}_{\text {hitung }}$ sebesar 36,134 dengan sig 0,000. Juga linier dibuktikan dengan diperoleh skor $\mathrm{F}_{\text {hitung }}$ sebesar 1,027 dengan sig 0,436. Dimana persamaan regresi tersebut menunjukan bahwa apabila iklim sekolah nilainnya 0 maka nilai efektivitas pembelajaran adalah 64, 208. Apabila iklim sekolah memiliki nilai 0,5042 mengalami peningkatan satu satuan maka efektivitas pembelajaran mengalami peningkatan sebesar 0,5042.

Hasil uji korelasi antara iklim sekolah dengan efektivitas pembelajaran diperoleh nilai korelasi sebesar 0,468 dengan sig. (2-tailed) $=0,00$ sedangkan nilai $\mathrm{a}=0,01$. Hal ini bahwa koefisien korelasi antara iklim sekolah dan efektivitas pembelajaran adalah sangat signifikan. Nilai koefisien sebesar 0,468 pada kriteria Guilford berada dalam rentang 0,400 - 0,700 artinya berada dalam kategori hubungan yang cukup. Dan nilai koefisien determinasi sebesar 0,219 atau 21,9\%. Dengan demikian, pengaruh iklim sekolah terhadap efektivitas pembelajaran adalah sebesar $21,9 \%$.

Mengacu pada hasil pengujian terhadap hipotesis pertama, disimpulkan bahwa $\mathrm{H}_{0}$ ditolak, artinya $\mathrm{H}_{1}$ (hipotesis diterima) menyatakan terdapat hubungan iklim sekolah $\left(\mathrm{X}_{1}\right)$ dengan efektivitas pembelajaran $(\mathrm{Y})$ adalah nyata

\section{Hubungan antara pengetahuan guru tentang kurikulum 2013 dengan efektivitas pembelajaran.}

Dari hasil perhitungan analisis korelasi, pengaruh langsung efikasi diri terhadap learning organization, nilai koefesien korelasi sebesar 0,476 dan nilai $t_{\text {hitung }}$ sebesar 6,32 serta nilai $t_{\text {tabel }}$ sebesar 1,98. Oleh karena itu nilai $t_{\text {hitung }}$ lebih besar dari nilai $\mathrm{t}_{\text {tabel }}$ maka dengan demikian $\mathrm{H}_{0}$ ditolah dan $\mathrm{H}_{1}$ diterima. Artinya bahwa terdapat hubungan positif antara efikasi diri dengan learning organization.

Persamaan regresi antara pengetahuan guru tentang kurikulum $2013\left(\mathrm{X}_{2}\right)$ dengan efektivitas pembelajaran $(\mathrm{Y})$ adalah $\hat{\mathrm{Y}}$ $=111,104+0,767 \mathrm{X}_{2}$ yang signifikan dibuktikan dengan diperoleh $\mathrm{F}_{\text {hitung }}$ sebesar 24,820 dengan sig 0,000. Dan linier dibuktikan dengan diperoleh skor $F_{\text {hitung }}$ sebesar 1,163 dengan sig 0,313. Dimana persamaan regresi tersebut menunjukan bahwa apabila pengetahuan guru tentang kurikulum 2013 nilainnya 0 maka nilai efektivitas pembelajaran adalah 111,1. Apabila pengetahuan guru tentang kurikulum 2013 memiliki nilai 0,7672 mengalami peningkatan satu satuan maka efektivitas pembelajaran mengalami peningkatan sebesar 0,7672.hasil uji korelasi antara pengetahuan guru tentang kurikulum 2013 dengan efektivitas pembelajaran diperoleh nilai korelasi sebesar 0,377 dengan sig. (2-tailed) $=0,00$ sedangkan nilai $a=0,05$. Hal ini bahwa 
koefisien korelasi antara pengetahuan guru tentang kurikulum 2013 dengan efektivitas pembelajaran adalah sangat signifikan. nilai koefisien korelasi sebesar 0,377. Nilai koefisien sebesar 0,377 dalam kriteria Guilford berada dalam rentang 0,200 - 0,400 artinya berada dalam kategori hubungan yang rendah tapi pasti. Mengacu pada tabel di atas diperoleh nilai Rsquare menunjukan kontribusi sebesar 0,142 atau 14,2\%. Dengan demikian, pengaruh pengetahan guru tentang kurikulum 2013 terhadap efektivitas pembelajaran adalah sebesar $14,2 \%$.

Mengacu pada hasil pengujian terhadap hipotesis kedua, disimpulkan bahwa $\mathrm{H}_{0}$ ditolak, artinya $\mathrm{H}_{1}$ (hipotesis diterima) menyatakan terdapat hubungan pengetahuan guru tentang kurikulum $2013\left(\mathrm{X}_{2}\right)$ dengan efektivitas pembelajaran (Y) adalah nyata.

\section{Hubungan antara iklim sekolah dan pengetahuan guru tentang kurikulum 2013 secara bersama-sama dengan efektivitas pembelajaran}

Persamaan regresi antara iklim sekolah dan pengetahuan guru tentang kurikulum 2013 secara bersama-sama dengan efektivitas pembelajaran adalah $\hat{\mathrm{Y}}=64,020+0,419 \mathrm{X}_{1}+0,522 \mathrm{X}_{2}$ yang signifikan dibuktikan dengan diperoleh nilai $\mathrm{F}_{\text {hitung }}$ sebesar 28,760 dengan sig 0,000. Uji korelasi antara iklim sekolah dan pengetahuan guru tentang kurikulum 2013 dengan efektivitas pembelajaran memiliki nilai koefisien korelasi sebesar 0,528. Nilai koefisien sebesar 0,528 dalam kriteria Guilford berada dalam rentang 0,400 - 0,700 berada dalam kategori hubungan yang cukup. Mengacu pada tabel di atas diperoleh nilai Rsquare menunjukan kontribusi simultan sebesar 0,279 atau 27,9\%. Dengan demikian, pengaruh pengetahan guru tentang kurikulum 2013 terhadap efektivitas pembelajaran adalah sebesar 27,9\%.

Mengacu pada hasil pengujian terhadap hipotesis ketiga, disimpulkan bahwa $\mathrm{H}_{0}$ ditolak, artinya $\mathrm{H}_{1}$ (hipotesis diterima) menyatakan terdapat hubungan iklim sekolah $\left(\mathrm{X}_{1}\right)$ dan pengetahuan guru tentang kurikulum $2013\left(\mathrm{X}_{2}\right)$ dengan efektivitas pembelajaran (Y) adalah nyata.

\section{Korelasi Parsial}

Pada variabel pengetahuan guru tentang kurikulum $2013\left(\mathrm{X}_{2}\right)$ sebagai kontrol, nilai koefisien korelasi parsial antara iklim sekolah $\left(\mathrm{X}_{1}\right)$ dengan efektivitas pembelajaran $(\mathrm{Y})$ diperoleh nilai 0,399 dengan nilai signifikansi sebesar 0,000 $<0,05$ hal ini menunjukkan bahwa hubungan antara iklim sekolah $\left(\mathrm{X}_{1}\right)$ dengan efektivitas pembelajaran $(\mathrm{Y})$, dimana skor pengetahuan guru tentang kurikulum $2013\left(\mathrm{X}_{2}\right)$ dikontrol adalah signifikan.

Pada variabel iklim sekolah $\left(\mathrm{X}_{1}\right)$ sebagai kontrol, nilai koefisien korelasi antara pengetahuan guru tentang kurikulum $2013\left(\mathrm{X}_{2}\right)$ dengan efektivitas pembelajaran $(\mathrm{Y})$ diperoleh nilai 0,276 dengan nilai signifikansi sebesar 0,001 < 0,05 hal ini menunjukkan bahwa hubungan antara pengetahuan guru tentang kurikulum $2013\left(\mathrm{X}_{2}\right)$ dengan efektivitas pembelajaran (Y), dimana skor iklim sekolah $\left(\mathrm{X}_{1}\right)$ dikontrol signifikan

Berdasarkan koefisien korelasi antara iklim sekolah dengan efektivitas pembelajaran dapat disimpulkan bahwa terdapat hubungan positif yang sangat signifikan antara iklim sekolah dengan efektivitas pembelajaran, karena diperoleh besarnya skor koefisien korelasi $r_{y 1}=0,468$. diperoleh sig. (2-tailed) $=0,00$. Hal ini bahwa koefisien korelasi antara iklim sekolah dan efektivitas pembelajaran adalah sangat signifikan.

Kontribusi iklim sekolah dalam menerangkan efektivitas pembelajaran melalui skor koefisien determinasi $\mathrm{r}_{\mathrm{y} 1}=0,219$ (21,9\%). Demikian menunjukkan 21,9\% efektivitas pembelajaran dapat diterangkan oleh iklim sekolah. Hasil penelitian menunjukkan terdapat hubungan positif yang sangat signifikan antara iklim sekolah dengan efektivitas pembelajaran dan hubungan tersebut merupakan hubungan fungsional yang memiliki arti bahwa peningkatan peran iklim sekolah dapat meningkatkan efektivitas pembelajaran..

Temuan penelitian ini mendukung penelitian sebelumnya yang dilakukan Manaf, A., \& Omar, C. M. Z. (2017:35) berjudul Improvement School Effectiveness through Culture and School Climate. Diterbitkan oleh The International Journal of Social Sciences and Humanities Invention, yang membuktikan terdapat hubungan positif yang signifikan antara iklim sekolah dengan efektivitas pembelajaran. Kekuatan hubungan antara keduanya ditunjukkan dengan koefisien korelasi (r) sebesar 0,422, p> 0,05. Berarti semakin tinggi iklim sekolah akan semakin tinggi pula efektivitas pembelajaran.

Berdasarkan hasil perhitungan koefisien korelasi antara pengetahuan guru tentang kurikulum $2013\left(\mathrm{X}_{2}\right)$ dengan efektivitas pembelajaran (Y) dapat disismpulkan bahwa terdapat hubungan positif yang sangat signifikan antara pengetahuan guru tentang kurikulum $2013\left(\mathrm{X}_{2}\right)$ dengan efektivitas pembelajaran $(\mathrm{Y})$. Karena diperoleh besarnya skor koefisien korelasi ry $2=$ 0,377. Kriteria pengujian signifikansi koefesien sig. < 0,05, diperoleh sig. (2-tailed) =0,00 sedangkan nilai a = 0,05. Hal ini bahwa koefisien korelasi antara pengetahuan guru tentang kurikulum 2013 dan efektivitas pembelajaran adalah sangat signifikan.

Kontribusi pengetahuan guru tentang kurikulum $2013\left(\mathrm{X}_{2}\right)$ dalam menerangkan efektivitas pembelajaran (Y) melalui skor koefisien determinasi $\mathrm{ry}_{2}=0,142(14,2 \%)$. Demikian menunjukkan 14,2\% efektivitas pembelajaran (Y) dapat diterangkan oleh pengetahuan guru tentang kurikulum $2013\left(\mathrm{X}_{2}\right)$.

Temuan penelitian ini mendukung penelitian sebelumnya yang dilaksanakan oleh Maria Liakopoulou (2011:70). Dengan judul penelitian "The Professional Competence of Teacher: Which Qualities, Attitudes, Skills and Knowledge Contribute to a Teacher's Effectiveness?” diterbitkan oleh International Journal of Humanities and Social Science terdapat 
hubungan positif antara pengetahuan guru tentang kurikulum $2013\left(\mathrm{X}_{2}\right)$ dengan efektivitas pembelajaran (Y). Karena Kualitas yang dapat memastikan efektivitas pengajaran bukan hanya jumlah pengetahuan yang dimiliki guru, melainkan hubungan antara berbagai jenis pengetahuan yang terdiri dari subjek pengetahuan, pengetahuan tentang metodologi pengajaran, kurikulum pengetahuan peserta didik, pengetahuan pedagogis yang umum, pengetahuan akan konteks, pengetahuan diri yang dimiliki oleh guru. Jenis-jenis pengetahuan ini tidak hanya hidup berdampingan dalam diri seorang guru tetapi harus membentuk unit pengetahuan yang lengkap dan tidak dapat dipisahkan. Hal tersebut mewujudkan guru kompeten yang berhasil menggabungkan sebagian bentuk pengetahuan ini. Sehingga pembelajaran yang efektif dapat optimal.

Berdasarkan hasil penelitian dapat disimpulkan bahwa terdapat hubungan positif yang sangat signifikan antara iklim sekolah $\left(\mathrm{X}_{1}\right)$ dan pengetahuan guru tentang kurikulum $2013\left(\mathrm{X}_{2}\right)$ dengan efektivitas pembelajaran (Y). Hasil uji signifikan korelasi ganda terdapat kekuatan hubungan antara iklim sekolah $\left(\mathrm{X}_{1}\right)$ dan pengetahuan guru tentang kurikulum $2013\left(\mathrm{X}_{2}\right)$ dengan efektivitas pembelajaran (Y) diperoleh $\mathrm{ry}_{12}=0,528$.

Hasil uji signifikansi korelasi ganda diperoleh $\mathrm{F}_{\text {hitung }}=28,760$ dengan sig 0,000, maka hipotesis yang diterima adalah $\mathrm{H}_{1}$. Dapat ditarik kesimpulan terdapat hubungan positif yang sangat signifikan antara iklim sekolah $\left(\mathrm{X}_{1}\right)$ dan pengetahuan guru tentang kurikulum $2013\left(\mathrm{X}_{2}\right)$ dengan efektivitas pembelajaran $(\mathrm{Y})$. Beradasarkan skor koefisien korelasi ry ${ }_{12}=0,528$ dapat diperoleh skor koefisien determinasi $\mathrm{r}_{2} \mathrm{y}_{12}=0,279$ atau 27,9\%. Dengan demikian, secara bersama-sama pengaruh iklim sekolah $\left(\mathrm{X}_{1}\right)$ dan pengetahuan guru tentang kurikulum $2013\left(\mathrm{X}_{2}\right)$ dengan efektivitas pembelajaran $(\mathrm{Y})$ adalah sebesar 27,9\% sedangkan sisanya sebesar $72,1 \%$ adalah kontribusi dari variabel lain yang tidak diteliti.

\section{SIMPULAN}

Terdapat hubungan positif yang sangat signifikan antara iklim sekolah dengan efektivitas pembelajaran. iklim sekolah mengakibatkan adanya peningkatan pula pada efektivitas pembelajaran. Terdapat hubungan yang sangat signifikan antara pengetahuan guru tentang kurikulum 2013 dengan efektivitas pembelajaran dimana hal tersebut menyatakan bahwa semakin besar pengetahuan guru tentang kurikulum 2013 maka dapat mengakibatkan peningkatan pada efektivitas pembelajaran. Terdapat hubungan positif yang signifikan antara iklim sekolah dan pengetahuan guru tentang kurikulum 2013 secara bersamasama dengan eefektivitas pembelajaran. Hal tersebut menyatakan bahwa semakin besar iklim sekolah dan pengetahuan guru tentang kurikulum 2013 secara bersama-sama maka mengakibatkan peningkatan pada efektivitas pembelajaran.

\section{REFERENSI}

Afadil, A., \& Poedjiastoeti, S. (2016). International Journal of Active Learning Effectiveness of Learning Based Problem Solving with Aspect Ontology, Epistemology, Axiology to Increase Critical Thinking Ability and Understanding Thermochemical Concept of Students. International Journal of Active Learning, 1(2)

Bao, Z., Li, D., Zhang, W., \& Wang, Y. (2015). School Climate and Delinquency Among Chinese Adolescents: Analyses of Effortful Control as a Moderator and Deviant Peer Affiliation as a Mediator. Journal of Abnormal Child Psychology, 43(1)

Bungai, Joni. (2006). Pengaruh Kompetensi Kepala Sekolah, Iklim Sekolah, dan Keefektifan Mengajar Terhadap Prestasi Lulusan SMA. Jurnal Ilmu Pendidikan. Vol 13, No 2. Universitas Negeri Malang.

Freiberg, H.J. (2005). School Climate Measuring, Improving and Sustaining Healty Learning Environment (e-library edition). Philadelphia: Falmer Press.

Goldstein, S., \& Brooks, R. B. (2013). Handbook of resilience in children: Second edition. Handbook of Resilience in Children: Second Edition, (June 2013) .

Hidayat, Rais, Henny Suharyati, Yuyun Elizabeth Patras, Sutji Harjanto, Haposan Andi. (2018). Optimalisasi Budaya Mutu Sekolah Untuk Meningkatkan Komitmen Guru. Jurnal Manajemen Pendidikan, Vol.6 No. 2, PP. 595-606

Herman WH, \& Cohen RM. (2018). Racial and ethnic differences in the relationship between HbA1c. Journal of Clinical Endocrinology \& Metabolism, 97(4)

Kemendikbud. (2013). Permendikbud No. 65 Tahun 2013 tentang Standar Proses Pendidikan Dasar dan Menengah.

Park, S., \& Oliver, J. S. (2008). Revisiting the Conceptualisation of Pedagogical Content Knowledge ( PCK ): PCK as a Conceptual Tool to Understand Teachers as Professionals. Springer Science + Business Media B.V, 38.

Pertiwi, R., \& Suchyadi, Y. (2019). Implementasi Program Pendidikan Karakter Di Sekolah Dasar Negeri Lawanggintung 01 Kota Bogor. Jurnal Pendidikan \& Pengajaran Guru Sekolah Dasar (JPPGuseda ), 02, 41-46. https://doi.org/10.33751/jppguseda.v2i1.994

Pratiwi, suryani dewi. (2013). Pengaruh Motivaasi Kerja, Kepuasan Kerja, Kepemimpinan Kepala Sekolah menurut Persepsi Guru dan Ikli, Sekolah terhadap Kinerja Guru aekonomi SMP Negeri di Kabupaten Wonogiri. Jurnal Pendidikan Insan Mandiri, 1(1),

Rapti, D. (2012). School Climate as an Important Component in School Effectiveness. Academicus - International Scientific Journal, (69).

Sheng, H., Siau, K., \& Nah, F. F.-H. (2010). Understanding the values of mobile technology in education. ACM SIGMIS 
Database, 41(2).

Supardi. (2013). Sekolah Efektif Konsep dasar dan Praktiknya. Depok: PT. Raja Grafindo Persada.

Timperley, H. (2008). Teacher professional learning and development Educational Practices Series - 18. International Academy of Education (IAE).

Yulita, H. (2014). Faktor-Faktor Yang Mempengaruhi Efektifitas Metode Pembelajaran E-Learning. Business \& Management Journal Bunda Mulia, 10(1). 